\title{
Political orientation and support for social distancing during the COVID-19 pandemic: evidence from Brazil
}

\author{
Guilherme Ramos ${ }^{1 *}$ \\ Yan Vieites ${ }^{1 *}$ \\ Jorge Jacob 23 \\ Eduardo B. Andrade 1 \\ ${ }^{1}$ Fundação Getulio Vargas / Brazilian School of Public and Business Administration, Rio de Janeiro / RJ - Brazil \\ 2 Columbia University, New York / NY - United States of America \\ 3 University of Virginia, Charlottesville / VA - United States of America
}

Social distancing practices have been widely recommended to curb the COVID-19 pandemic. However, despite the medical consensus, many citizens have resisted adhering to and/or supporting its implementation. While this resistance may stem from the non-negligible personal economic costs of implementing social distancing, we argue that it may also reside in more fundamental differences in normative principles and belief systems, as reflected by political orientation. In a study conducted in Brazil, we test the relative importance of these explanations by examining whether and how support for social distancing varies according to self-identified political orientation and personal economic vulnerability. Results show that while economic vulnerability does not influence support for social distancing, conservatives are systematically less supportive of these practices than liberals. Discrepancies in sensitivity to threats to the economic system help explain the phenomenon.

Keywords: COVID-19; political orientation; social distancing; public policy.

\section{Orientação política e apoio ao isolamento social durante a pandemia da COVID-19: evidências do Brasil}

Práticas de isolamento social têm sido amplamente recomendadas para conter a propagação da pandemia da COVID-19. No entanto, apesar do consenso médico, muitos cidadãos têm resistido a aderir e/ou apoiar a sua implementação. Enquanto essa resistência pode ter origem nos custos econômicos individuais não desprezíveis de implementar o isolamento social, argumentamos que ela também pode residir em diferenças mais fundamentais nos princípios normativos e sistemas de crenças, refletidos na orientação política. Em um estudo conduzido no Brasil, testamos a importância relativa dessas explicações ao examinar se e como o apoio ao isolamento social varia de acordo com orientação política autodeclarada e vulnerabilidade econômica pessoal. Os resultados mostram que enquanto a vulnerabilidade econômica não influencia o apoio ao isolamento social, indivíduos que se consideram de direita apoiam sistematicamente menos tais práticas do que aqueles que se consideram de esquerda. Diferenças em suas sensibilidades a ameaças ao sistema econômico ajudam a explicar o fenômeno.

Palavras-chave: COVID-19; orientação política; isolamento social; política pública.

\section{Orientación política y apoyo al aislamiento social durante la pandemia de COVID-19: evidencia de Brasil}

Las prácticas de aislamiento social se han recomendado ampliamente para contener la propagación de la pandemia de COVID-19. Sin embargo, a pesar del consenso médico, muchos ciudadanos se han resistido a adherirse y/o apoyar su implementación. Si bien esta resistencia puede provenir de costos económicos personales no despreciables en la implementación del aislamiento social, argumentamos que también puede residir en diferencias más fundamentadas en principios normativos y sistemas de creencias, reflejados en la orientación política. El artículo prueba, mediante una encuesta realizada en Brasil, la importancia relativa de estas explicaciones al examinar si y de qué manera el apoyo al aislamiento social varía de acuerdo con la orientación política declarada y la vulnerabilidad económica personal. Los resultados muestran que, si bien la vulnerabilidad económica no influye en el apoyo al aislamiento social, los conservadores apoyan dichas prácticas sistemáticamente menos que los liberales. Las diferencias de sensibilidad ante las amenazas al sistema económico ayudan a explicar el fenómeno.

Palabras clave: COVID-19; orientación política; aislamiento social; política pública.

DOI: http://dx.doi.org/10.1590/0034-761220200162x

Article received on April 13, 2020 and accepted on June 18, 2020.

[Original version]

* These authors contributed equally to this work. 


\section{INTRODUCTION}

As of June $10^{\text {th }}$, there were more than 7 million confirmed cases and 400 thousand fatalities due to the Coronavirus disease 2019 (COVID-19) worldwide. In response to the pandemic, international and local health agencies converged in recommending the early implementation of strict social distancing policies to curb the spread of the virus (Tabari et al., 2020; World Health Organization, 2020). However, despite the medical consensus, many citizens have been reluctant to adopt these control measures (Tanne, 2020). This research investigates the role played by political orientation in shaping attitudes and behaviors concerning social distancing policies.

Political polarization is alive and well in Brazil (Samuels \& Zucco, 2014). In fact, it has been on the rise over the last decades across the globe (Carothers \& O'Donohue, 2019), and this trend shows no sign of stopping (Abramowitz \& Saunders, 2008; Mansbridge, 2016). In the US, for instance, the share of people self-identified as liberal (i.e., left-wing) or conservative (i.e., right-wing) increased from 57\% in 1992 to 65\% in 2010 (Saad, 2012). As political orientation increases in importance, preferences become more clearly divided along ideological lines. Liberals and conservatives have been shown to display different opinions on a wide variety of issues, from gun control to climate change (Gramlich \& Schaeffer, 2019; VanBoven et al., 2018). Given that political orientation largely shapes opinions on public policy (Bail et al., 2018; Dimock \& Carroll, 2014), people's views on social distancing may also hold a strong relationship with their position in the political spectrum.

At the heart of the discussions about the adoption of social distancing measures is the apparent trade-off between public health and economic well-being. In many regions of the world, people have ascribed to the view that due to a brutal and lasting economic impact, stringent and earlier social distancing measures could be as or even more harmful to society than softer isolation policies or no policy at all (Snooks, 2020). Although many have eventually changed their minds, a few still resist (The Lancet, 2020). While this resistance may be rooted in non-negligible personal costs of implementing social distancing, it may also reside in more fundamental differences in normative principles and belief systems. To test the relative importance of these explanations, we examine the association between support for social distancing and two measures: (a) economic vulnerability (i.e., social class and anticipated impact on one's personal finances), and (b) political orientation, which is at the core of the presumed trade-off between public health and economic well-being.

Although the health and economic consequences of social distancing may impact both liberals and conservatives alike, the latter may be much more sensitive to the possible economic effects of adopting strict social distancing measures. Unlike liberals, conservatives consider institutions such as businesses and industries as key aspects of society (Choma et al., 2014; Kerlinger, 1984). They also tend to endorse protestant work values, which emphasize the importance of continuous hard work (Atieh et al., 1987), and oppose increased public spending (Jacoby, 2000; Rudolph \& Evans, 2005), a traditional measure used to alleviate the economic losses inflicted by social distancing. Therefore, we hypothesize that conservatives will be systematically less supportive of social distancing practices and policies than liberals. Further, this association should be, at least in part, explained by their differences in sensitivity to threats to the economic system.

This research offers a number of contributions to the literature. First, while previous research has called the influence of political orientation and party identification into question (Converse, 
1964; Fiorina, 2006), recent work shows that the predictive power of political orientation on policy preferences is particularly pronounced (Dimock \& Carroll, 2014; Bail et al., 2018). In light of the gravity of the problem at stake and the relative consensus about its solution, the COVID-19 pandemic offers a critical test for the importance of political orientation in shaping policy support. Second, thus far, research has emphasized the role of perceived health risks to the self to explain the relationship between political orientation and support for social distancing measures (Alcott et al., 2020; Barrios \& Hochberg, 2020; Conway III et al., 2020; Painter \& Qiu, 2020; Rosenfeld et al., 2020). We advance these findings by introducing a new mechanism into the discussion: sensitivity to threats to the economic system. Finally, while evidence for the effect of political orientation on adherence to social distancing measures already exists, it is overwhelmingly based on US data. However, whether a given issue becomes politically polarized or not depends on idiosyncratic regional characteristics (McCright, Dunlap, \& Marquart-Pyatt, 2016). We therefore further contribute to the literature by examining the robustness of the phenomenon in Brazil.

\section{STUDY}

\subsection{Methods}

Following a recent trend in the behavioral sciences (Nosek et al., 2018), we conducted a preregistered experimental study. Prior to analyzing the data, we submitted our hypotheses and the analytical plan to an independent registry (https://aspredicted.org/blind.php?x=4er5ui). Overall, albeit not a panacea (Yamada, 2018), pre-registration is an important practice in academia insofar as it lends credibility to research by reducing questionable practices such as hypothesizing after the results are known and p-hacking (Miguel et al., 2014; Munafò et al., 2017; Nosek et al., 2018; Yamada, 2018).

As outlined in the pre-registration report, we tested the relative importance of political orientation vis-à-vis economic vulnerability (e.g., social class, anticipated impact on personal earnings) in predicting support for social distancing. Although not anticipated in the preregistration, we conducted exploratory mediation analyses to assess whether this effect could be explained by sensitivity to threats to the economic system. The pre-registration protocol also included hypotheses about three different interventions designed to bolster support for social distancing. However, given that none of these interventions systematically swayed attitudes and behavior, we followed the suggestions of the review team to put less emphasis on it in the paper. We detail them in the appendix.

Participants. Participants were recruited in Brazil through the authors' networks and social media between March $24^{\text {th }}$ and March $27^{\text {th }}$, 2020. In exchange for their participation, they were told that we would donate $\mathrm{R} \$ 1$ per participant to a social cause related to mitigating the impacts of COVID-19. Although 1,053 people took part in this study, only 768 of them met all the inclusion criteria established in the pre-registration. Specifically, participants were excluded from the sample if they failed to complete the study or chose the "I don't know" option in any of the dependent variables. 
Procedure. Upon providing their consent, participants were randomly assigned to one of four experimental conditions, which were part of the hypothesis we elaborate in the appendix. Next, all participants proceeded to the dependent variables. First, we asked how much they supported the adoption of social distancing practices for about one month ( 1 =strongly against, $4=$ strongly in favor). Second, we asked how strict the governmental social distancing policies should be ( $1=$ no policy, $4=$ strong and immediate policy). Third, they completed a consequential measure of the type of cause they were willing to donate the compensation for their participation ( $1=$ a cause aimed at mitigating impacts of the pandemic on health, $0=$ on the economy). While the first two dependent measures were attitudinal, the third one captured a consequential behavior that reflected more explicitly the trade-off between economy and public health.

Next, participants filled a socio-demographic questionnaire. Embedded in this questionnaire was a 4-point scale of political orientation. Even though we use the labels "liberals" and "conservatives" throughout the article for the sake of consistency with the international literature, our questionnaire actually employed the meaningful terms for political orientation in Brazil — "left-wing" and "rightwing," respectively (Hasson et al., 2018; Jost, Federico, \& Napier, 2009). This measure read "in terms of political orientation, how do you classify yourself?" (1=clearly left-wing; $4=$ clearly right-wing; also including an "I do not know what it means to be left- or right-wing" option). Additionally, this sociodemographic questionnaire also included: (a) a measure of anticipated impact on personal earnings in case the participant had to comply with social distancing ( $1=$ at least partially affected, $0=$ not affected; also including a "cannot predict" option), (b) a 5-point measure of subjective social class ( $1=$ my income is much below the average of the Brazilian population; $5=$ much above the average), and (c) questions about education and income, which following prior literature (Adler et al., 2000; Korndörfer, Egloff, \& Schmukle, 2015), were standardized and collapsed into a single composite measure of objective social class. While political orientation captures people’s belief systems and normative principles, anticipated impact on personal earnings and social class both served as measures of economic vulnerability.

Finally, we asked participants about the dimension of their personal lives that would likely be the most affected by the pandemic ( 1 =finances, $0=$ health or security). We asked the same about the lives of close others (e.g., family, neighbors, community) and of people in society in general (e.g., fellow Brazilians). These variables sought to capture, respectively, relative sensitivity to threats to personal finances, to close others' finances, and to the economic system as a whole. Further, we collected measures of exposure to the Coronavirus, as well as other usual demographic questions (e.g., age, gender, ethnicity, marital status, geographic region) for descriptive purposes only. Participants were then thanked and dismissed.

Analytical Plan. We tested the effects of political orientation, social class, and anticipated impact on personal earnings on our three dependent measures: decision to donate to the health- (vs. economy-) related cause and support for social distancing practices and policies. We used logistic regressions for the donation decision variable and linear regression models for the two social distancing measures. To investigate the mediating role of relative sensitivity to threats to the economic system, and compare it with the effect of threats to the self and to one's community, we conducted seemingly unrelated regressions, which allow for a simultaneous estimation of equations. 


\section{RESULTS AND DISCUSSION}

Data description. Table 1 displays the summary statistics. Our sample is composed by a majority of female, white and upper-class people, living in the south and southeast regions of Brazil. By the time the study was conducted, only a small percentage of the participants had been tested for COVID-19, but $16 \%$ of them knew someone who had tested positive. Further, participants seemed to be well distributed along the political spectrum. A Shapiro-Wilk test on our measure of political orientation suggests that participants followed a normal distribution ( $\mathrm{W}=1.00, \mathrm{z}=-1.49, \mathrm{p}=.93)$.

\section{TABLE $1 \quad$ SUMMARY STATISTICS}

\begin{tabular}{|c|c|c|c|c|c|}
\hline Variables & Mean & SD & Min & Max & $\mathrm{N}$ \\
\hline \multicolumn{6}{|l|}{ Controls } \\
\hline Men & 0.39 & 0.49 & 0 & 1 & 768 \\
\hline Age & 37.81 & 12.46 & 18 & 72 & 768 \\
\hline White & 0.79 & 0.41 & 0 & 1 & 768 \\
\hline Religiosity & 2.86 & 1.48 & 1 & 5 & 768 \\
\hline Married & 0.48 & 0.50 & 0 & 1 & 768 \\
\hline Southeast Region & 0.67 & 0.47 & 0 & 1 & 768 \\
\hline South Region & 0.20 & 0.40 & 0 & 1 & 768 \\
\hline Northeast Region & 0.07 & 0.26 & 0 & 1 & 768 \\
\hline Health Sector & 0.21 & 0.41 & 0 & 1 & 768 \\
\hline Tested for Coronavirus & 0.03 & 0.18 & 0 & 1 & 768 \\
\hline Positive Result & 0.00 & 0.04 & 0 & 1 & 768 \\
\hline Acquaintance Positive & 0.16 & 0.37 & 0 & 1 & 768 \\
\hline \multicolumn{6}{|l|}{ Independent Variables } \\
\hline Conservative (Scale) & 2.46 & 0.95 & 1 & 4 & 747 \\
\hline Anticipated Impact on Earnings & 0.39 & 0.49 & 0 & 1 & 543 \\
\hline Subjective SES & 4.13 & 1.04 & 1 & 5 & 774 \\
\hline
\end{tabular}




\begin{tabular}{|c|c|c|c|c|c|}
\hline Variables & Mean & SD & Min & Max & N \\
\hline Objective SES & 0.00 & 0.80 & -3.70 & 3.84 & 730 \\
\hline Years of Education & 16.66 & 1.82 & 5 & 18 & 774 \\
\hline Household income & 14789 & 11322 & 500 & 40000 & 730 \\
\hline \multicolumn{6}{|l|}{ Dependent Variables } \\
\hline Support Social Distancing Practices & 3.49 & 0.74 & 1 & 4 & 768 \\
\hline Support Social Distancing Policies & 3.58 & 0.64 & 1 & 4 & 768 \\
\hline Donation to Health (vs. economy) & 0.70 & 0.46 & 0 & 1 & 768 \\
\hline
\end{tabular}

Source: Elaborated by the authors.

Data Analyses. As mentioned before, we performed the analyses for the donation decision variable using logistic regressions, and for the two social distancing measures using linear regression models. Thus, we regressed each of these outcomes on political orientation, objective and subjective social class, and anticipated impact on personal earnings. To avoid omitted variable biases and help provide more accurate estimations, we controlled for the participants' age, gender, race, religiosity, marital status, geographic region of residence, whether s/he worked in the health sector, whether friends or family members had tested positive for COVID-19, and day of participation in the study. We present different specifications to attest to the robustness of the results.

Surprisingly, neither social class nor anticipated impact on personal earnings consistently shaped support for social distancing and/or donation decisions (see table 2). In sharp contrast, and consistent with our expectations, political orientation systematically predicted support for social distancing and donation decisions. As shown in Figure 1, the more the participants selfidentified as conservatives (vs. liberals), the less supportive of both social distancing practices $(\beta=-.30, t(498)=-8.91, p<.001)$ and policies $(\beta=-.23, t(498)=-7.43, p<.001)$ they were. They were also less likely to donate to the health-related cause $(\beta=-.21, z=-1.85, p=.06)$. Importantly, among the predictors, political orientation had the strongest effect on social distancing practices and policies ${ }^{1}$. Overall, these findings highlight the substantial importance of political orientation in predicting support for social distancing. Interestingly, these effects outweighed the importance of economic vulnerability.

\footnotetext{
${ }^{1}$ We reran models 6 and 9 using standardized coefficients to analyze the relative importance of each variable in explaining support for social distancing. Political orientation was by far the strongest predictor $\left(\beta_{\text {practices }}=-.37 ; \beta_{\text {policies }}=\right.$ -.34). The second-strongest predictor had about half of this effect.
} 


\section{TABLE 2 EFFECTS OF POLITICAL ORIENTATION ON SUPPORT FOR SOCIAL DISTANCING AND} DONATIONS TO THE HEALTH CAUSE

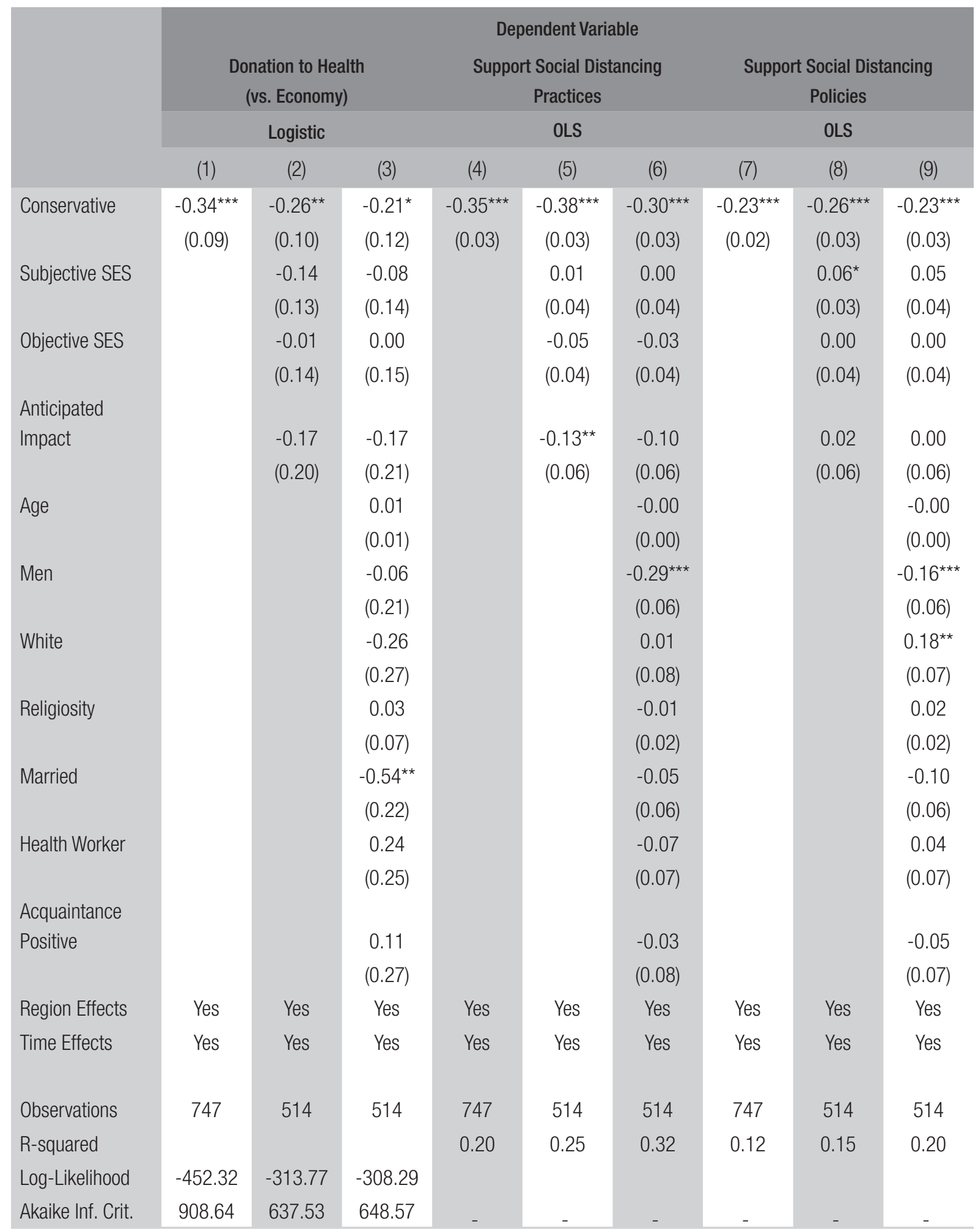

Note: Standard errors in parentheses. ${ }^{* *} \mathrm{p}<0.01,{ }^{* *} \mathrm{p}<0.05,{ }^{*} \mathrm{p}<0.10$

Source: Elaborated by the authors. 
Panel A:

Support for the Practice of Social Distancing

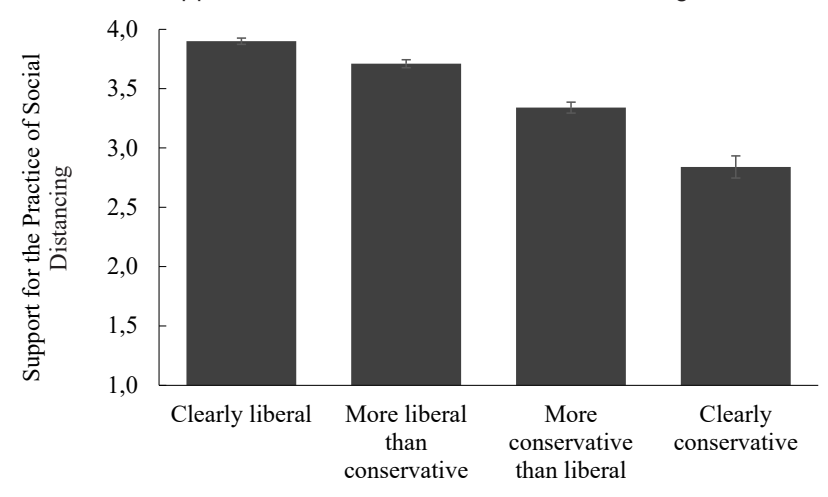

Panel B

Support for Social Distancing Policies

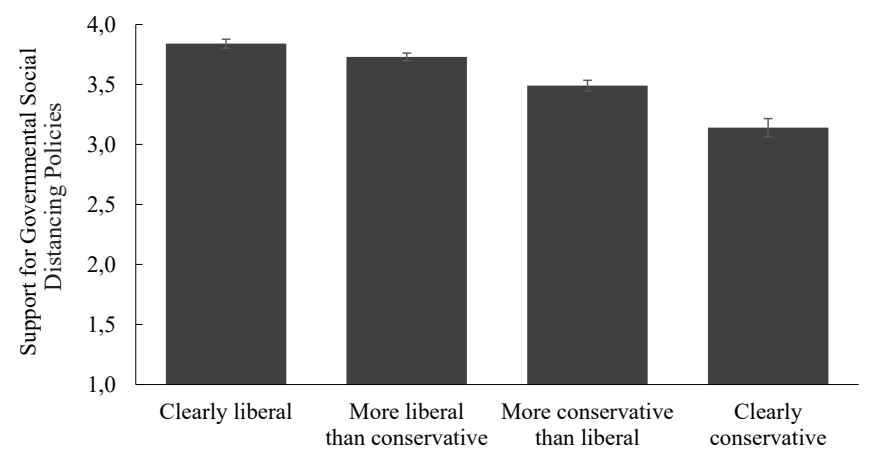

Panel C

Likelihood of Donating to the Health-Related Cause

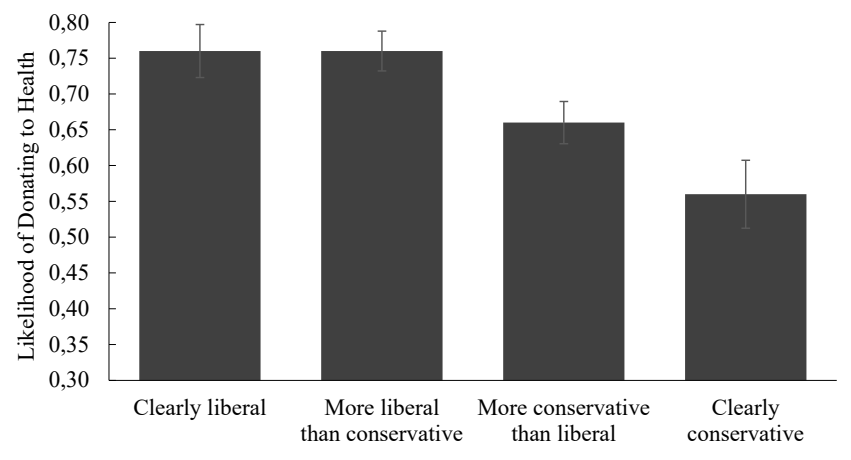

Source: Elaborated by the authors.

Economy vs. Health. As highlighted in the introduction of the paper, conservatives and liberals display fundamental differences in values and belief systems. Conservatives are likely to give more weight to the detrimental economic effects of social distancing than liberals when facing the apparent trade-off between the health-related consequences of the disease and the expected economic side effects of social distancing. The significant differences in donation preferences shown above (Figure 1 Panel C) converge with this assumption. 
Along these lines, we also examined whether the lower support for social distancing practices and policies and the lower donation rates for the health-related cause among conservatives (vs. liberals) could be explained by a greater relative sensitivity to the possible threats to the economic system. Although it is important to acknowledge that we had not anticipated this possibility in the pre-registration, our data allow us to test it empirically.

As outlined in the procedure, we collected measures assessing the participants' relative sensitivity to economic threats (finances $=1$, health or security $=0$ ) at the levels of the self, close community, and society. To analyze the relative importance of sensitivity to threats to the economic system, we conducted a series of seemingly unrelated regressions with 5,000 replications to test parallel mediation models for each of the dependent variables.

As shown in figure 2 (Panels A-C), and consistent with our rationale, conservatives' (vs. liberals') higher likelihood of donating to the economic-related cause was significantly mediated by relative sensitivity to economic threats to society ( $\beta_{\text {society }}=-.03, z=-3.94$, bootstrap 95\% CI=[-.043, -.014$\left.]\right)$, but not by economic threats to oneself or to one's community ( $\beta_{\text {self }}=-.01, \mathrm{z}=-1.48$, bootstrap $95 \% \mathrm{CI}=[-.016$, $.002] ; \beta_{\text {close community }}=-.01, z=-1.91$, bootstrap $\left.95 \% \mathrm{CI}=[-.016, .000]\right)$. In addition, while participants' relative sensitivity to economic threats to society significantly mediated the relationship between political orientation and social distancing practices $\left(\beta_{\text {society }}=-.02, z=-3.04\right.$, bootstrap $95 \% \mathrm{CI}=[-.041$, $-.009]$ ), evidence for the effects in more personal levels was mixed ( $\beta_{\text {self }}=-0.02, z=-2.18$, bootstrap $95 \% \mathrm{CI}=[-.031,-.002] ; \beta_{\text {close community }}=-.01, z=-1.68$, bootstrap $\left.95 \% \mathrm{CI}=[-.019, .001]\right)$. Finally, the effect of political orientation on support for social distancing policies was mediated by participants' relative sensitivity to economic threats to society $\left(\beta_{\text {society }}=-.02, \mathrm{z}=-2.77\right.$, bootstrap $\left.95 \% \mathrm{CI}=[-.035,-.006]\right)$, but evidence for the effects in more personal levels failed to reach significance $\left(\beta_{\text {self }}=-.01, z=-1.43\right.$, bootstrap 95\% CI $=[-.020, .003] ; \beta_{\text {close community }}=-.005, z=-1.07$, bootstrap $\left.95 \% \mathrm{CI}=[-.013, .004]\right)$. Taken together, these findings converge with the idea that political orientation shapes support for social distancing through more general values and belief systems rather than sheer selfish motives (i.e., a concern about the economic consequences of social distancing or the close community).

\section{FIGURE 2 (PANELS A-C) - THE MEDIATING ROLE OF RELATIVE SENSITIVITY TO ECONOMIC THREATS}

Panel A

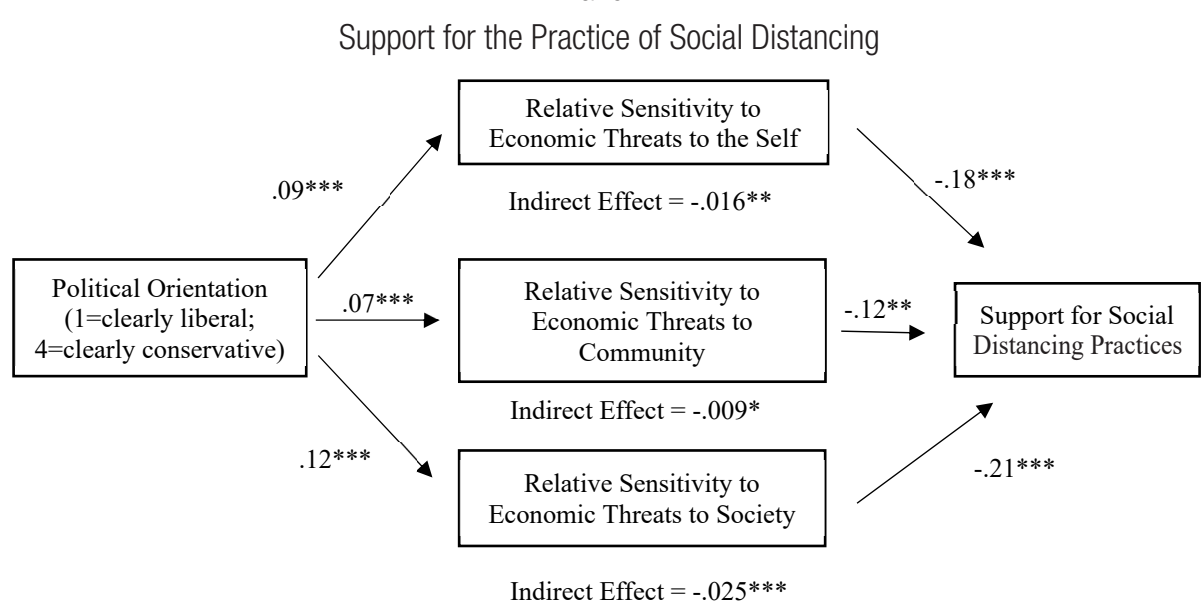


Panel B

Support for Social Distancing Policies

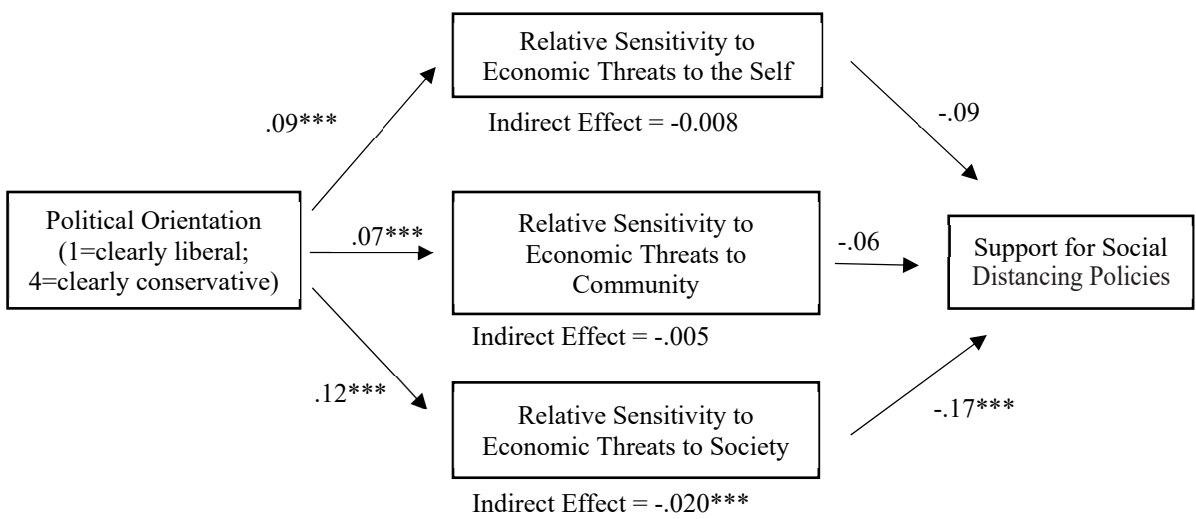

Panel C

Likelihood of Donating to the Health-Related Cause

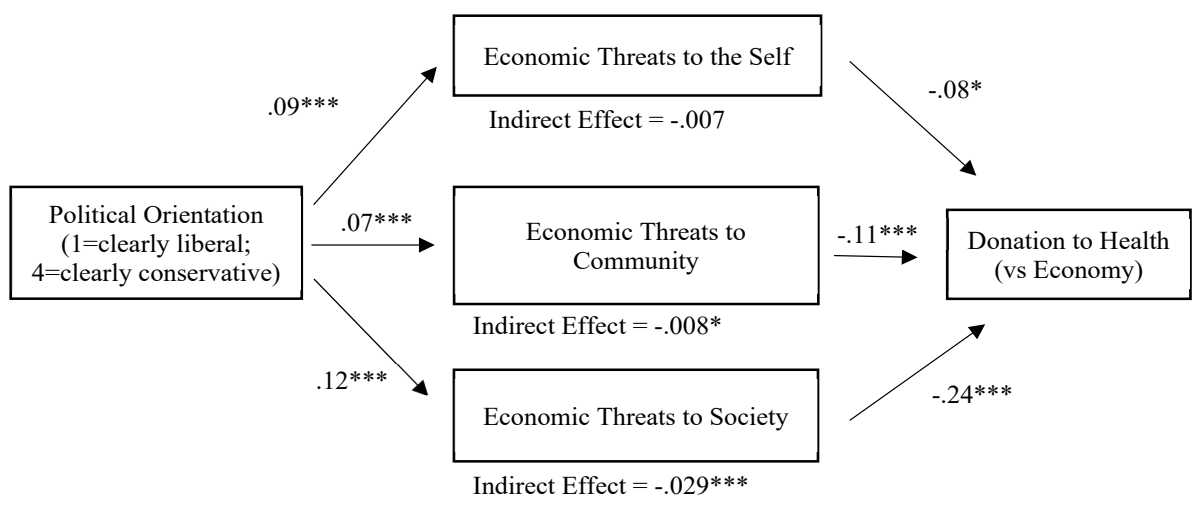

Source: Elaborated by the authors.

\section{GENERAL DISCUSSION}

The COVID-19 outbreak has engendered a staggering number of deaths worldwide. Yet, based on the argument that stringent and earlier social distancing measures could be as or even more harmful to society than softer distancing policies or no policy at all (Snooks, 2020), many citizens have shown reluctance to adhere to and/or to support social distancing, despite the medical consensus. While this resistance might be rooted in significant personal economic costs of implementing social distancing, it is also possible that the lack of support for such measures might reflect more abstract normative principles and belief systems, the core of which is political orientation (Jost et al., 2009). The current research investigated the relative importance of political orientation vis-à-vis economic vulnerability in predicting support for social distancing and consequential donation decisions. Consistent with our predictions, political orientation shaped support for social distancing above and beyond personal economic vulnerability, which, somewhat surprisingly, did not consistently influence support for social distancing. More specifically, conservatives were systematically less supportive of social distancing practices and policies when compared to their liberal counterparts. Further, in a more explicit test of the trade-off between public health and economic well-being, political orientation also predicted 
consequential donation decisions to a cause aimed at mitigating the health (vs. economic) impacts of the COVID-19 pandemic. Mediation analyses lent additional support for the idea that the phenomenon is rooted in abstract belief systems rather than on personal economic vulnerability.

Admittedly, we are not the first to investigate the link between political orientation and support for social distancing. Emerging research in the context of the COVID-19 pandemic has provided consistent support for the claim that political orientation predicts support for social distancing (Alcott et al., 2020; Barrios \& Hochberg, 2020; Conway III et al., 2020; Painter \& Qiu, 2020; Rosenfeld et al., 2020). More broadly, research on political orientation and policy support has documented that people tend to value policies favored by their own political group and to devalue policies advocated by the opposing political group (Gadarian, Goodman, \& Pepinsky, 2020; Van Boven, Ehret, \& Sherman, 2018). In contrast to these line of research, we focus on the role of abstract normative principles and belief systems. Further, past research has shown that whether a given issue becomes politically polarized or not depends on idiosyncratic regional characteristics (McCright, Dunlap, \& MarquartPyatt, 2016). While the extant evidence for the effect of political orientation on adherence to social distancing measures is overwhelmingly based on US data, we move the debate away from the US by examining the robustness of the phenomenon in Brazil.

Our study also has important practical implications for public communication. Conservatives tend to be less favorable toward social distancing because they are more sensitive to the economic threats to society this measure apparently imposes. While this pandemic seems to have inevitable negative consequences for the economy, previous research has shown that early and strict adoption of preventive measures (e.g., social distancing) actually have positive effects on economic growth after the pandemic, and therefore contributes to faster economic recovery (Correia, Luck, \& Verner, 2020). Thus, rather than enhancing economic depression, the adoption of social distancing measures seems to mitigate it, thereby breaking down the trade-off. Policy-makers can therefore highlight this feature in public communications in order to enhance compliance with, and support for, social distancing among conservatives.

This study does not come without limitations, however. First, our sample is not representative of the Brazilian population. Given the pressingness of the issue and the data collection restrictions imposed by the virus, the overwhelming majority of studies on the COVID-19 pandemic share this limitation (Di Lorenzo et al., 2020; Marta et al., 2020; Padala, Jendro, \& Padala, 2020). Nation-wide data collections with representative samples are therefore needed to attest to the external validity of the phenomenon. Second, our sample's strong support for social distancing suggests the existence of ceiling effects. Future research could employ alternative measures of support for social distancing to mitigate this concern. Third, we are mindful that our data have been collected at a single time period within an unprecedented moment. Therefore, not only the results of this investigation warrant replication but also future investigations should account for potential variation in public policy guidance or social perception on the COVID-19 pandemic. Nonetheless, our findings show clearly the power of political orientation, over and above personal economic considerations, on shaping health protection attitudes and behavior during the COVID-19 pandemic in Brazil. 


\section{REFERENCES}

Abramowitz, A. I., \& Saunders, K. L. (2008). Is polarization a myth?. The Journal of Politics, 70(2), 542-555.

Adler, N. E., Epel, E. S., Castellazzo, G., \& Ickovics, J. R. (2000). Relationship of subjective and objective social status with psychological and physiological functioning: Preliminary data in healthy, White women. Health psychology, 19(6), 586.

Allcott, H., Boxell, L., Conway, J., Gentzkow, M., Thaler, M., \& Yang, D. Y. (2020). Polarization and public health: Partisan differences in social distancing during the Coronavirus pandemic (NBER Working Paper). Cambridge, MA: The National Bureau of Economic Research.

Atieh, J. M., Brief, A. P., \& Vollrath, D. A. (1987). The Protestant work ethic-conservatism paradox: Beliefs and values in work and life. Personality and Individual Differences, 8(4), 577-580.

Bail, C. A., Argyle, L. P., Brown, T. W., Bumpus, J. P., Chen, H., Hunzaker, M. F., ... \& Volfovsky, A. (2018). Exposure to opposing views on social media can increase political polarization. Proceedings of the National Academy of Sciences, 115(37), 9216-9221.

Barrios, J. M., \& Hochberg, Y. (2020). Risk perception through the lens of politics in the time of the covid-19 pandemic (NBER Working Paper). Cambridge, MA: The National Bureau of Economic Research.

Carothers, T., \& O'Donohue, A. (Eds.). (2019). Democracies divided: The global challenge of political polarization. Washington, DC: Brookings Institution Press.

Choma, B. L., Hanoch, Y., Hodson, G., \& Gummerum, M. (2014). Risk propensity among liberals and conservatives: The effect of risk perception, expected benefits, and risk domain. Social Psychological and Personality Science, 5(6), 713-721.

Converse, P. E. (1964). “The Nature of Belief Systems in Mass Publics." In D. E. Apter (Ed.), Ideology and Its Discontents (pp. 206-261). New York, NY: The Free Press of Glencoe.

Conway III, L. G., Woodard, S. R., Zubrod, A., \& Chan, L. (2020, April 13). Why are conservatives less concerned about the coronavirus (COVID-19) than liberals? Testing experiential versus political explanations. PsyArXiv.

Correia, S., Luck, S., \& Verner, E. (2020, June 05). Public Health Interventions Do Not: Evidence from the 1918 Flu (Working Paper). SSRN.

Di Lorenzo, G., Toniolo, P., Lurani, C., Foresti, L., \& Carrisi, C. (2020). Evaluating the adequacy of Prima Covid-19 IgG/IgM Rapid Test for the assessment of exposure to SARS-CoV-2 virus. medRxiv.

Dimock M, Carroll D. (2014). "Political polarization in the American public: How increasing ideological uniformity and partisan antipathy affect politics, compromise, and everyday life". Washington, DC: Pew Research Center.

Fiorina, M. F. P., Abrams, S. J. \& Pope, J. C. (2006). Culture War? The Myth of a Polarized America (2nd ed.). New York, NY: Pearson Longman.

Gadarian, S. K., Goodman, S. W., \& Pepinsky, T. B. (2020, March 27). Partisanship, health behavior, and policy attitudes in the early stages of the COVID-19 pandemic (Working Paper). SSRN.

Gramlich, J. \& Schaeffer, K. (2019). "7 facts about guns in the U.S.". Washington, DC: Pew Research Center.

Hasson, Y., Tamir, M., Brahms, K. S., Cohrs, J. C., \& Halperin, E. (2018). Are liberals and conservatives equally motivated to feel empathy toward others?. Personality and Social Psychology Bulletin, 44(10), 1449-1459.

Jacoby, W. G. (2000). Issue framing and public opinion on government spending. American Journal of Political Science, 750-767.

Jost, J. T., Federico, C. M., \& Napier, J. L. (2009). Political ideology: Its structure, functions, and elective affinities. Annual review of psychology, 60, 307-337.

Kerlinger, F. (1984). Liberalism and conservatism: The nature and structure of social attitudes. Hillsdale, NJ: Lawrence Erlbaum.

Korndörfer, M., Egloff, B., \& Schmukle, S. C. (2015). A large scale test of the effect of social class on prosocial behavior. PloS one, 10(7), e0133193.

Lancet, T. (2020). COVID-19: learning from experience. Lancet (London, England), 395(10229), 1011. 
Loewenstein, G., Read, D., \& Baumeister, R. F. (Eds.). (2003). Time and decision: Economic and psychological perspectives of intertemporal choice. New York, NY: Russell Sage Foundation.

Mansbridge. (2016, March 11). Three reasons political polarization is here to stay. The Washington Post. Retrieved from https://www.washingtonpost.com/ news/in-theory/wp/2016/03/11/three-reasonspolitical-polarization-is-here-to-stay/

Marta, I., Mirjana, Đ., Aleksandar, K., Filip, M., Kristina, N., Tamara, P., ... Irena, T. (2020). Serbian Citizens' Opinion on the COVID-19 Epidemic. South Eastern European Journal of Public Health (SEEJPH). Retrieved from https://doi.org/10.4119/seejph-3459

McCright, A. M., Dunlap, R. E., \& Marquart-Pyatt, S. T. (2016). Political ideology and views about climate change in the European Union. Environmental Politics, 25(2), 338-358.

Miguel, E., Camerer, C., Casey, K., Cohen, J., Esterling, K. M., Gerber, A., ... Van der Laan, M. (2014). Promoting transparency in social science research. Science, 343, 30-31.

Munafò, M. R., Nosek, B. A., Bishop, D. V. M., Button, K. S., Chambers, C. D., du Sert, N. P., ... Ioannidis, J. P. A. (2017). A manifesto for reproducible science. Nature Human Behavior 1, 1-9.

Nosek, B. A., Ebersole, C. R., DeHaven, A. C., and Mellor, D. T. (2018). The preregistration revolution. Proceedings of the National Academy of Sciences, 18, 201708274.

O’Donoghue, T., \& Rabin, M. (2015). Present bias: Lessons learned and to be learned. American Economic Review, 105(5), 273-79.

Padala, P. R., Jendro, A. M., \& Padala, K. P. (2020). Conducting clinical research during the COVID-19 Pandemic: Investigator and participant perspectives. JMIR Public Health and Surveillance, 6(2), e18887.

Painter, M., \& Qiu, T. (2020, April). Political beliefs affect compliance with covid-19 social distancing orders (Working Paper) SSRN.
Rosenfeld, D. L., Rothgerber, H., \& Wilson, T. (2020). Politicizing the covid-19 pandemic: Ideological differences in adherence to social distancing. PsyArXiv.

Rudolph, T. J., \& Evans, J. (2005). Political trust, ideology, and public support for government spending. American Journal of Political Science, 49(3), 660-671.

Saad, L. (2012). "Conservatives Remain the Largest Ideological Group in U.S.". Retrieved from http:// www.gallup.com/poll/152021/conservativesremain-largest-ideological-group.aspx

Samuels, D., \& Zucco, C., Jr. (2014). The power of partisanship in Brazil: Evidence from survey experiments. American Journal of Political Science, 58(1), 212-225.

Snooks, G. D. (2020). Fight the Virus (COVID-19), Not the Economy!. Institute of Global Dynamic Systems (Working Paper, 20). Canberra, Australia: Institute of Global Dynamic Systems.

Tabari, P., Amini, M., Moghadami, M., Moosavi, M. (2020). International Public Health Responses to COVID-19 Outbreak: A Rapid Review. Iranian Journal of Medical Sciences, 45(3), 157-169.

Tanne, Janice Hopkins (2020), "Covid-19: cases grow in US as Trump pushes promise of a malaria drug." BMJ (Clinical research ed.), 368, m1155.

Van Boven, L., Ehret, P. J., \& Sherman, D. K. (2018). Psychological barriers to bipartisan public support for climate policy. Perspectives on Psychological Science, 13(4), 492-507.

World Health Organization (2020, January), "Household transmission investigation protocol for 2019-novel coronavirus ( 2019-nCoV ) infection," EarlyInvestigations-2019, 1-31.

Yamada, Y. (2018). How to crack pre-registration: Toward transparent and open science. Frontiers in psychology, 9, 1831. 


\section{Guilherme Ramos}

https://orcid.org/0000-0003-3519-3861

Master in Business Administration; Ph.D. Student in Business Administration from Brazilian School of Public and Business Administration at Fundação Getulio Vargas. E-mail: guilhermedearamos@yahoo.com.br

\section{Yan Vieites}

https://orcid.org/0000-0001-5708-109X

Master in Business Administration; Ph.D. Candidate in Business Administration from Brazilian School of Public and Business Administration at Fundação Getulio Vargas. E-mail: yan.vieites@gmail.com

\section{Jorge Jacob}

https://orcid.org/0000-0001-6786-3706

Ph.D. in Business Administration; Postdoctoral Researcher at Columbia University \& University of Virginia. E-mail: jr3815@columbia.edu

\section{Eduardo B. Andrade}

https://orcid.org/0000-0002-2930-8151

Ph.D. in Marketing; Professor of Consumer Psychology from Brazilian School of Public and Business Administration at Fundação Getulio Vargas. E-mail: eduardo.b.andrade@fgv.br 


\section{APPENDIX}

\section{THE PRESENT BIAS HYPOTHESIS}

Part of the reason people may be reluctant to adopt social distancing may be "present bias" (O’Donoghue and Rabin 2015). The implementation of, and adherence to, social distancing can be thought of as a classic intertemporal choice problem (Loewenstein, Read, and Baumeister 2003). Whereas the benefit of a reduction in the number of deaths takes time to come to fruition, governments and society must incur the cost of social distancing in the early stages of the outbreak. If the health consequences of the pandemic are yet to come, citizens and policy-makers may feel reluctant to incur the certain and earlier psychological and financial burden associated with social distancing in hopes of a probabilistic future benefit. In this research, we attempted to "bring the future to the present" by inducing a subset of participants to reflect upon the health consequences of the pandemic (i.e., to predict the number of deaths or to make a morally difficult medical decision). Our hypothesis predicted that increasing the salience of the health consequences of the pandemic would increase support for social distancing.

In order to test this hypothesis, we randomly assigned individuals to one of four experimental conditions where they (a) were not exposed to any intervention (baseline condition); (b) were asked which group of patients should be prioritized in case resources in hospitals were insufficient (medical decision condition); (c) estimated the number of victims of the COVID-19 in the subsequent 5 days in several countries and were then presented with the actual data (estimated death toll condition-5 days); or (d) made the exact same estimation for the subsequent 10 days (estimated death toll condition-10 days). All these interventions were designed to increase the salience of the potential health consequences of the pandemic. Next, the participants proceeded to the dependent variables and then to the socio-demographic questionnaire as detailed in the article.

Results. We analyzed the effects of the interventions on the donation decision using logistic regression, and on the two other social distancing measures using linear regression models (see table A1). As depicted in Figure A1, none of our interventions consistently increased support for social distancing or donations to the health-related cause. Part of the reason may be the fact that, in our sample, the support for social distancing practices $\left(\mathrm{M}_{\text {baseline }}=3.51, \mathrm{SD}=.71\right)$ and policies $\left(\mathrm{M}_{\text {baseline }}=3.58\right.$, $\mathrm{SD}=.66)$ were quite high. Consistent with it, the only exception was that participants in the medical decision condition were more likely to donate to a health-related cause than those in the baseline condition ( $\beta=.63, \mathrm{z}=2.91, \mathrm{p}=.004)$. For this metric, ceiling effects were less likely (Baseline=.66). Thus, we did not find support for this hypothesis. 


\title{
FIGURE A1 EFFECTS OF INTERVENTIONS ON SUPPORT FOR SOCIAL DISTANCING AND DONATIONS TO THE HEALTH-RELATED CAUSE
}

\author{
Panel A
}

Support for the Practice of Social Distancing

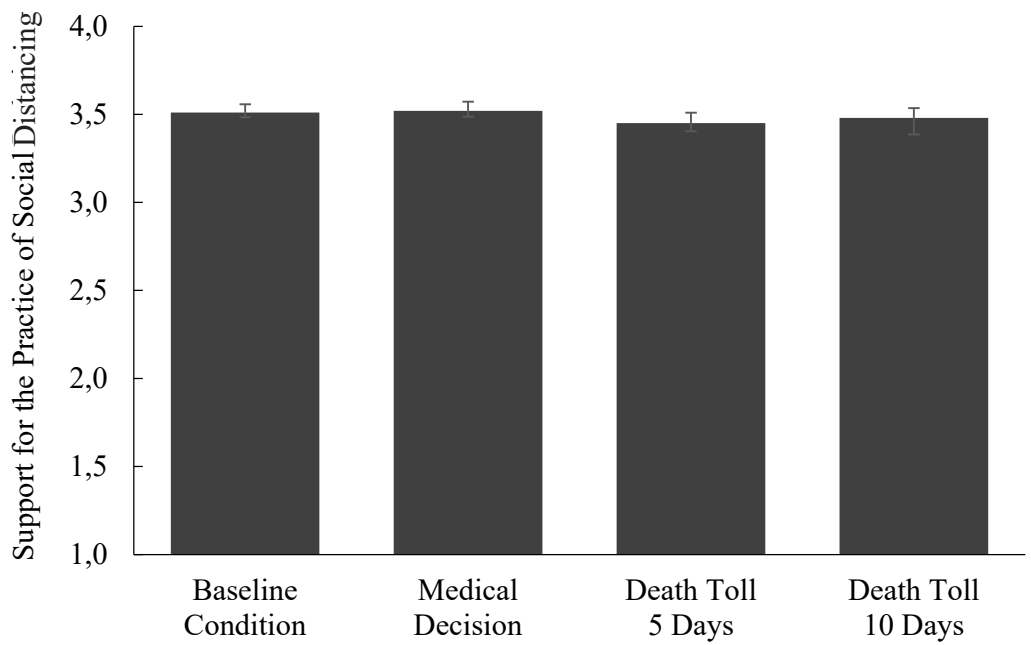

Panel B

Support for Social Distancing Policies

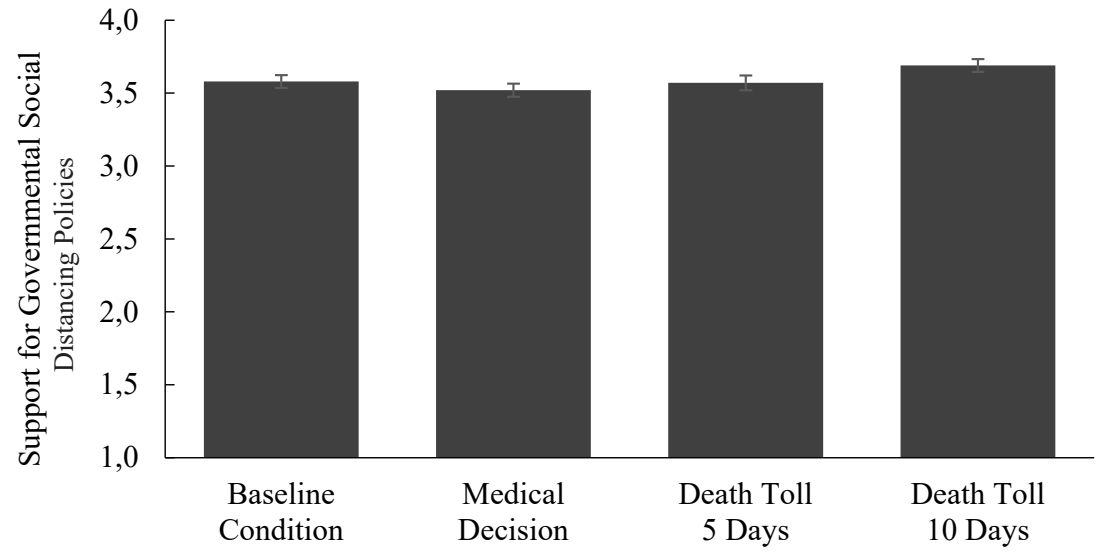

Panel C

Likelihood of Donating to the Health-Related Cause

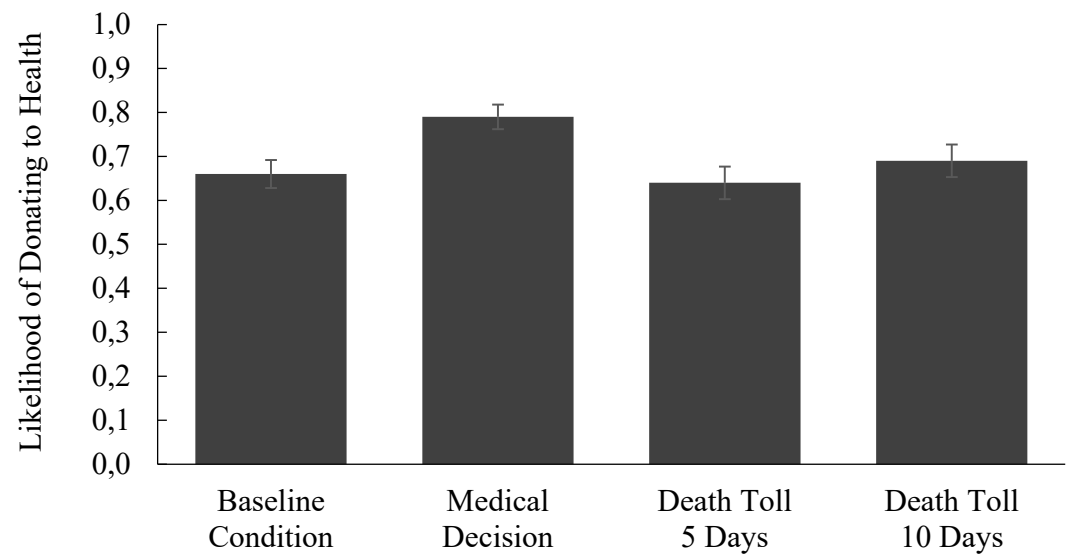

Source: Elaborated by the authors. 
RAP | Political orientation and support for social distancing during the COVID-19 pandemic: evidence from Brazil

\section{TABLE A1 EFFECT OF INTERVENTIONS ON SUPPORT FOR SOCIAL DISTANCING AND DONATION TO HEALTH-RELATED CAUSES}

\begin{tabular}{|c|c|c|c|}
\hline & \multicolumn{3}{|c|}{ Dependent Variable } \\
\hline & Donation to Health & $\begin{array}{c}\text { Support Social } \\
\text { Distancing Practices }\end{array}$ & $\begin{array}{c}\text { Support Social } \\
\text { Distancing Policies }\end{array}$ \\
\hline & Logistic & OLS & OLS \\
\hline & (1) & (2) & (3) \\
\hline \multirow[t]{2}{*}{ Medical Decision Condition } & $0.63^{\star \star \star}$ & 0.01 & -0.06 \\
\hline & $(0.22)$ & $(0.07)$ & $(0.06)$ \\
\hline \multirow[t]{2}{*}{ 10-days Estimates Condition } & 0.13 & -0.02 & $0.11^{\star}$ \\
\hline & $(0.22)$ & $(0.08)$ & $(0.07)$ \\
\hline \multirow[t]{2}{*}{ 5-days Estimates Condition } & -0.08 & -0.06 & -0.01 \\
\hline & $(0.21)$ & $(0.08)$ & $(0.07)$ \\
\hline Observations & 768 & 768 & 768 \\
\hline R-squared & & 0.00 & 0.01 \\
\hline Log-Likelihood & -464.34 & & \\
\hline Akaike Inf. Crit. & 936.69 & & \\
\hline
\end{tabular}

Note: Standard errors in parentheses. ${ }^{* *} \mathrm{p}<0.01,{ }^{* *} \mathrm{p}<0.05,{ }^{*} \mathrm{p}<0.10$

Source: Elaborated by the authors. 